Nota Científica

\title{
Anomalías celulares en larvas de ostra japonesa (Crassostrea gigas) provenientes de cultivo*
}

\author{
Marcelo González A., Patricia Rojas Z. y Mariel Campalans B. \\ Escuela de Ciencias del Mar. Universidad Católica de Valparaíso \\ Casilla 1020, Valparaíso, Chile
}

Recibido 12 mayo 1998; versión corregida 27 enero 1999; aceptado 8 marzo 1999.

RESUMEN. Larvas velígeras de ostra japonesa (Crassostrea gigas) fueron analizadas ultraestructuralmente, observándose dentro de la cavidad gastrointestinal cuerpos esféricos los cuales corresponderían a un hongo marino similar a Hyalochlorella sp. Además se describen cuerpos densos de tamaño variable que se encuentran en células ciliadas del velo, que estarían asociados a daño tisular, siendo el primer registro de estas anomalías en larvas cultivadas en el sur de Chile.

Palabras claves: ostra japonesa, ultraestructura, larva, Crassostrea gigas, patología.

\section{Celular anomalies in cultured Japanese oyster larvae (Crassostrea gigas)*}

\begin{abstract}
Cultured larvae of the Japanese oyster (Crassostrea gigas) were analyzed ultrastructurally. Spherical bodies inside the gastro-intestinal cavity were observed. These structures seem to be marine fungus similar to Hyalochlorella sp. Dense cellular bodies of variable size found in ciliated cells of the velum are also described, they would be associated with tissue damage. This is the first record for these abnormalities in larvae cultured in the south of Chile.
\end{abstract}

Key words: Japanese oyster, larvae, ultrastructure, Crassostrea gigas, pathology.

\section{INTRODUCCIÓN}

En los últimos años varias enfermedades infecciosas han sido detectadas en los moluscos provenientes de cultivo, en diversos lugares del mundo (Elston, 1994 ). En Chile, pocos trabajos hacen referencia a enfermedades o a posibles patógenos de moluscos cultivados, ya que los esfuerzos se han centrado principalmente en la identificación de parásitos metazoarios en poblaciones naturales, habiéndose dedicado poco esfuerzo a conocer los patógenos de los moluscos en condiciones de cultivo (Carvajal, 1988). En cambio, en otros países, se han reportado patógenos, como virus, bacterias y protozoos que están involucrados en la mortalidad de individuos en cultivo (Elston, 1994). En larvas de ostra Japonesa (Crassostrea gigas) se ha investigado principalmente la enfermedad viral que afecta al velo, conocida como OVVD (Elston y Wilkinson, 1985) la que produce elevadas mortalidades en criaderos.

* Estudio financiado por el proyecto FIP 95-32.
En el presente trabajo se describen dos anomalías celulares observadas en larvas de Crassostrea gigas provenientes de cultivo, que aunque son similares a las reportadas por Elston (1980) para la misma especie en la zona de Long Island (New York, USA), corresponden al primer registro de éstas en larvas cultivadas en la zona sur de Chile.

\section{MATERIALES Y MÉTODOS}

Larvas velígeras de Crassostrea gigas se obtuvieron desde un centro de cultivo en la localidad de Chinquihue (Puerto Montt, Chile). Los ejemplares fueron fijados en glutaraldehido al 2,5 \% en agua de mar microfiltrada $(0,22 \mu \mathrm{m})$ por 1 a 2 horas, se extrajo el exceso de fijador con dos lavados con agua de mar microfiltrada y posteriormente se dejaron en buffer cacodilato $0,1 \mathrm{M}$ por 1 hora. Se postfijaron durante 1 hora en tetróxido de osmio al $1 \%$ y se tiñeron en bloque con acetato de uranilo por 1 hora. Posteriormente se descalcificaron en una solución de EDTA al $5 \%$ en buffer cacodilato $0,1 \mathrm{M}$ por 45 
minutos. Se deshidrataron en una serie de alcohol en concentración creciente y se incluyeron en resina epóxica (Sigma). Se obtuvieron cortes de $1 \mu \mathrm{m}$ en un ultramicrótomo Reichert los cuales se tiñeron con azul de toluidina al $1 \%$. Los cortes ultrafinos se montaron en grillas de cobre y se tiñeron con citrato de plomo. Los cortes seleccionados se observaron en un microscopio de transmisión Zeiss EM 900.

\section{RESULTADOS Y DISCUSIÓN}

En el tracto gastrointestinal de las larvas se observó la presencia de un cuerpo esférico de unas 6 a $7 \mu \mathrm{m}$ de diámetro; éste está constituido por una pared externa, en la cual se pueden reconocer dos zonas de diferente electrodensidad, la zona externa es menos electrodensa que la interna. Las esferas presentan un citoplasma que se caracteriza por ser densamente granulado y contener muchas vacuolas. No fue posible reconocer otros organelos como aparato de Golgi o mitocondrias (Fig. 1).

Estos cuerpos esféricos encontrados en el presente estudio, comparten similitudes ultraestructurales con las descripciones realizadas por Elston (1980) para larvas de Crassostrea gigas, principalmente en el tamaño de las esferas y la morfología de la pared celular. Por sus semejanzas ultraestructurales este autor los asocia con el hongo marino Hyalochlorella marina. Las esferas encontradas en el presente estudio corresponderían a un hongo, que comparte similitudes morfológicas con Hyalochlorella sp., aunque se hace necesaria la realización de estudios más profundos para lograr aclarar su taxonomía. La presencia de este hongo en el tracto gastrointestinal de las larvas podría tener un impacto sobre las funciones normales de la glándula digestiva.

Por otra parte, en células epiteliales ciliadas del velo, se observaron acumulaciones electrodensas de gran tamaño $(0,5$ a $1,5 \mu \mathrm{m}$ de diámetro) ubicadas preferentemente cercanas a la superficie celular (Fig. 2). Algunas de estas células presentan un grado avanzado de degeneración citoplasmática, además de separación y rompimiento de la membrana plasmática (Fig. 3).

Las acumulaciones de material electrodenso en el citoplasma de células epiteliales también han sido descritas por Elston (1980) en células no ciliadas del manto de larvas de ostra japonesa. En el presente estudio, en cambio, las acumulaciones electrodensas están asociadas a las células ciliadas del manto. Estas acumulaciones podrían representar productos anormales del metabolismo celular y no parecen estar relacionados con partículas semejantes a virus o a un parásito intracelular ya que su ultraestructura no se corresponde con algún agente conocido. El rompimiento de la membrana plasmática, observado en algunas de las células que contienen las acumulaciones, permitiría la entrada de agentes patógenos como virus y bacterias.

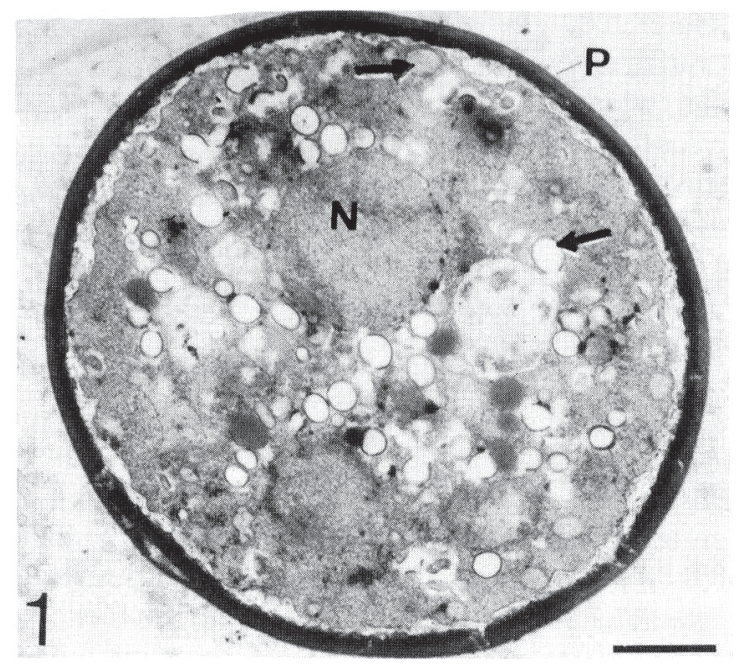

Figura 1. Microfotografía electrónica de transmisión de un cuerpo esférico en la cavidad gastrointestinal de una larva velígera de $C$. gigas. Núcleo $(\mathrm{N})$, vacuolas (flechas), pared $(\mathrm{P})$. Barra $=1 \mu \mathrm{m}$.

Figure 1. Transmission electron photomicrography showing a spherical body from gastro-intestinal cavity of a veliger larva of $C$. gigas. Nucleus $(\mathrm{N})$, vacuoles (arrows), wall $(\mathrm{P})$. Scale bar $=1 \mu \mathrm{m}$. 


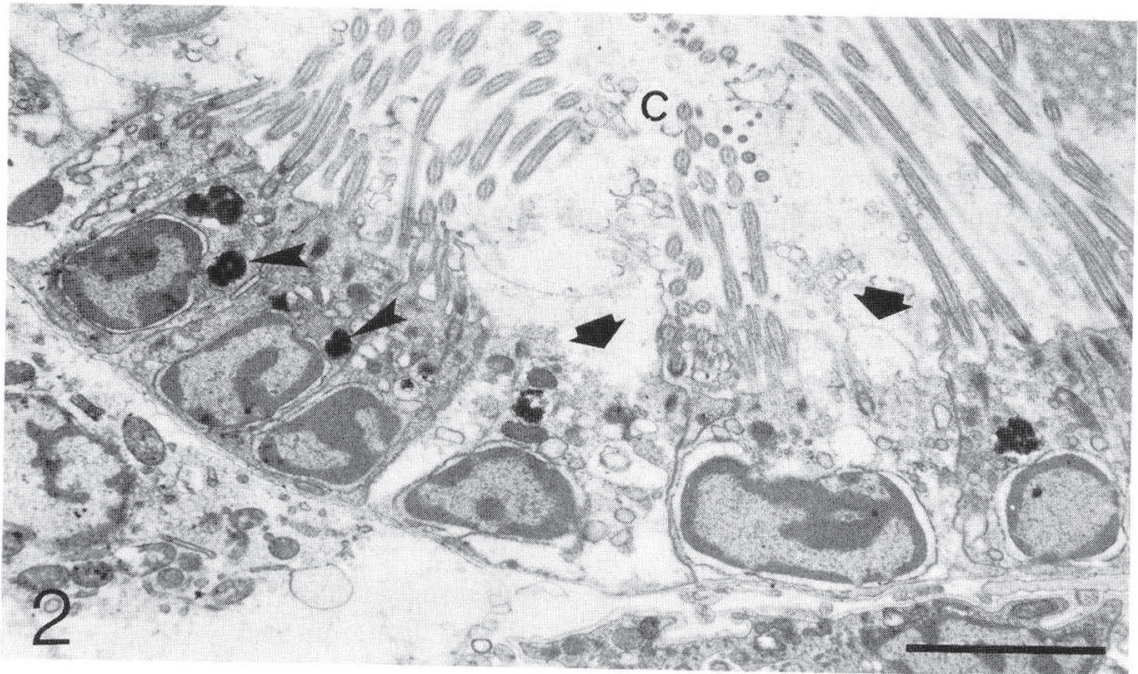

Figura 2. Células epiteliales del velo de una larva de $C$. gigas en las que se observan concentraciones anormales de cuerpos densos (cabezas de flecha), asociados al rompimiento de la membrana plasmática (flechas). cilios (C). Barra $=5 \mu \mathrm{m}$.

Figure 2. Velar epithelial cells of a $C$. gigas larva showing concentrations of abnormal dense bodies (arrowheads), associated with the plasmatic membrane rupture (arrows). cilia (C). Scale bar= $5 \mu \mathrm{m}$.

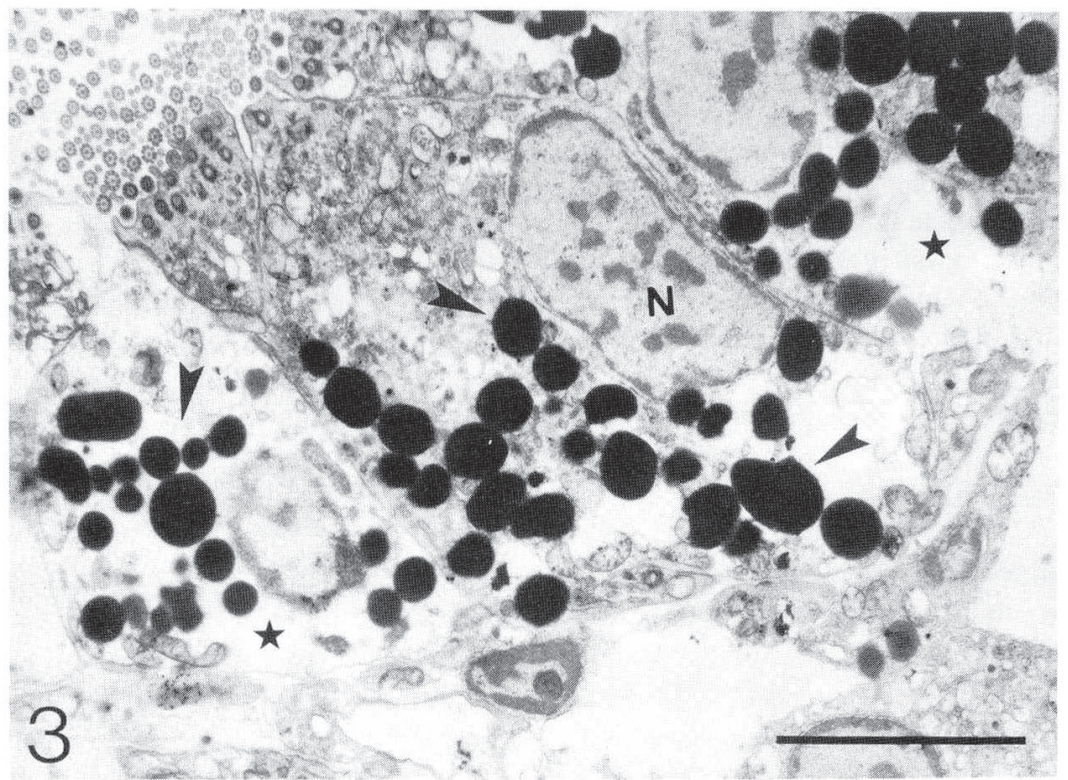

Figura 3. Células epiteliales del velo de una larva de $C$. gigas en las que se observan cuerpos densos (cabezas de flecha) asociados con degeneramiento citoplasmático (e). Núcleo (N). Barra= $5 \mu \mathrm{m}$.

Figure 3. Velar epithelial cells of a $C$. gigas larva showing concentrations of abnormal dense bodies (arrowheads), associated with cytoplasmic degeneration (e). nucleus (N). Scale bar $=5 \mu \mathrm{m}$. 


\section{REFERENCIAS}

Carvajal, J. 1988. Patología de moluscos y repoblación. Invest. Pesq. (Chile) 35: 123-128.

Elston, R. A. 1980. Ultrastructural aspects of a serius disease of hatchery reared larval oysters, Crassostrea gigas Thünberg. J. Fish Deseases, 3: 1-10.
Elston, R A. y M. T. Wilkinson. 1985. Pathology, management and diagnosis of oyster velar virus disease (OVVD). Aquaculture, 48: 189-210.

Elston, R. A. 1994. Diseases of Shellfish. In: J.C.Thoesen (ed.). Suggested procedures for the detection and identification of certain finfish and sellfish pathogens. 4th ed., Version 1, Fish Health Section, American Fisheries Society. 344 pp 